\title{
Molecular and Chemical Taxonomic Differentiation of Candida boidinii Ramirez Strains
}

\author{
YI-HUI LIN, FWU-LING LEE, ${ }^{*}$ AND WEN-HAW HSU \\ Food Industry Research and Development Institute, \\ Hsinchu 300, Taiwan, Republic of China
}

\begin{abstract}
Molecular and chemical taxonomic characteristics, including DNA base composition, electrophoretic karyotype, restriction fragment length polymorphism of genes coding for rRNA, cellular fatty acid composition, and ubiquinone systems, were studied for 19 strains of Candida boidinii Ramirez. Electrophoretic karyotype and restriction fragment length polymorphism demonstrated marked differences among these strains. A combination of molecular and chemical analyses can serve as a reliable tool for culture authentication and quality control of industrial strains.
\end{abstract}

The use of methylotrophic yeasts for the production of single cell proteins, alcohol oxidase, and fine chemicals has been proposed elsewhere (25). This potential stimulated researchers to study the physiology, biochemistry, and genetics of these organisms. Many new strains of methanol-assimilating yeasts have been isolated $(9,11)$. However, knowledge of their taxonomy is incomplete.

The characteristics of methanol-assimilating yeasts, including DNA base composition, coenzyme Q systems, proton magnetic resonance spectra of cell wall mannans, and electrophoretic patterns of enzymes, have been well examined (8, 11-13). Studies have shown that methanol-assimilating yeasts can be divided into four groups. Candida boidinii is the only species in group 1, characterized by low $\mathrm{G}+\mathrm{C}$ content of DNA and proton magnetic resonance spectra of cell wall mannans (12), which is type 18-p described by Gorin and Spencer (5). Lee and Komagata (13) found that nine strains of $C$. boidinii could be divided into two clusters on the basis of their enzyme electrophoretic patterns and $\mathrm{G}+\mathrm{C}$ contents. They described the two clusters as two chemovarieties of $C$. boidinii. Candida koshuensis, Candida methanolica, and Kloeckera sp. strain 2201 have been reidentified as Candida boidinii Ramirez on the basis of morphological, biological, and chemotaxonomic characteristics (12). Candida olivarium, Candida queretana, and Candida silvicola var. melibiosica were also considered synonyms of $C$. boidinii (1).

Molecular methods are being increasingly used in taxonomy for a better understanding of relationships among yeasts. Restriction fragment length polymorphisms (RFLPs) of the genes coding for rRNAs (rDNAs) have been used successfully to demonstrate inter- and intraspecific differences in yeasts (14, $16,18,22)$. Recently, the fingerprinting of the region composed of the $3^{\prime}$ external transcribed spacer (ETS) and the intergenic spacer (IGS) outside the rDNA-transcribed unit has been used to distinguish among three closely related Saccharomyces species (17). In the present study, we compared 19 strains of $C$. boidinii on the basis of phenotypic characteristics, cellular fatty acid composition, ubiquinone systems, DNA base composition, and electrophoretic karyotypes. Furthermore, we employed PCR to amplify the two spacer regions, ETS and IGS, and then used RFLP analysis to elucidate their interrelationships.

Nineteen strains of $C$. boidinii were studied (Table 1). Mor-

* Corresponding author. Mailing address: Food Industry Research and Development Institute, P.O. Box 246, Hsinchu 300, Taiwan, Republic of China. Phone: 886-35-223191. Fax: 886-35-214016. phological and physiological characteristics were investigated by the methods described by van der Walt and Yarrow (21).

For cellular fatty acid composition, the strains were cultivated in the liquid medium described by Smith et al. (19) and were collected during the late stationary phase of growth. Fatty acids were analyzed by gas chromatography by the method described by Ikemoto et al. (6).

To determine ubiquinone systems, cells were grown in the liquid medium described by Billon-Grand (2) and were collected at the early stationary phase. The cells were lyophilized, and ubiquinones were extracted and purified by the method described by Collins et al. (4). The purified quinones were analyzed by high-performance liquid chromatography (HPLC) and eluted with a methanol-isopropanol $(2: 1$ [ $\mathrm{vol} / \mathrm{vol}])$ mobile phase. A Nova-Pak C18 column (Waters) was employed.

For determination of DNA base composition, the yeast cells were grown in YPD (2\% glucose, $2 \%$ peptone, $1 \%$ yeast extract) broth and harvested in the late-exponential phase of growth. Isolation and purification of DNA were performed by the method described by Kaneko and Banno (7). The purified DNA was hydrolyzed to nucleosides as described by Tamaoka and Komagata (20), and the hydrolysate was analyzed by reverse-phase HPLC.

Karyotype electrophoresis. The cells examined were grown on YM agar (Difco) slants at $25^{\circ} \mathrm{C}$ for 1 to 2 days, harvested, and washed twice with $0.05 \mathrm{M}$ EDTA $(\mathrm{pH} \mathrm{7.5)}$ ) and were used to prepare agarose blocks according to the method described by Carle and Olson (3). Electrophoresis was carried out by the contour-clamped homogeneous electric field (CHEF) system with a hexagonal electrode array (Bio-Rad Laboratories) as described by Vollrath and Davis (24).

RFLP of rDNA. Prior to amplification with PCR, each DNA sample was adjusted to a concentration of $10 \mathrm{ng} / \mu \mathrm{l}$. PCR was performed according to the instructions of the manufacturer (Perkin-Elmer Cetus) on a 9600 thermal cycler with primer pairs 5S2 and ETS2. The two primers described by Molina et al. (17) defined the region spanning from base position 3110 on the $26 \mathrm{~S}$ rRNA to base position 27 on the 5S rRNA. The sequences of the primers were $5^{\prime} \mathrm{CACCGTTTCCCGTCCGATC}$ for 5S2 and 5'CTGAACGCCTCTAAGTC for ETS2. The amplification program consisted of predenaturation at $94^{\circ} \mathrm{C}$ for 5 min and 30 cycles at $94^{\circ} \mathrm{C}$ for $1 \mathrm{~min}, 60^{\circ} \mathrm{C}$ for $45 \mathrm{~s}$, and $72^{\circ} \mathrm{C}$ for $1 \mathrm{~min}$ according to the method described by Molina et al. (17). PCR products were purified with a Qiaquick-spin PCR purification kit (Qiagen) and then digested with a series of 10 endonucleases: MspI, RsaI, AluI, HaeIII, CfoI, HinfI, DdeI, Bst UI, Acil, and RmaI. Restriction fragments were electrophoresed 
TABLE 1. Strains of $C$. boidinii used in this study

\begin{tabular}{lll}
\hline \multicolumn{2}{c}{ Strain designation $^{a}$} & \\
\hline CCRC & CBS & \multicolumn{1}{c}{ Source } \\
\hline $20464^{\mathrm{T}}$ & 2428 & Tanning fluid, Spain \\
20472 & & Water, Germany \\
21432 & 8106 & Soil \\
21483 & 8052 & Soil \\
21758 & 8051 & Soil \\
22516 & 2429 & Soil, South Africa \\
22517 & 3092 & Alpechin, Spain \\
22518 & 5325 & Water, Fla. \\
22519 & 5777 & Wine, Japan \\
22520 & 6056 & Dry ginger ale, United States \\
22521 & 6202 & Floor of hospital ward, Finland \\
22522 & 6295 & Soil, The Netherlands \\
22523 & 6368 & Washed soft-drink bottles \\
22524 & 6510 & Rotten tomato, Japan \\
22525 & 6774 & Unknown \\
22526 & 6990 & Tepache, Mexico \\
22527 & 7067 & Milky liquid, France \\
22528 & 7447 & Production line, The Netherlands \\
22529 & 8251 & Soil, Poland \\
\hline
\end{tabular}

${ }^{a}$ CCRC, Culture Collection and Research Center, Food Industry and Development Institute, Taiwan, Republic of China; CBS, Centraalbureau Voor Schimmelcultures, Delft, The Netherlands.

on a $3 \%$ NuSieve 3:1 agarose gel (FMC Bioproducts) in $0.5 \times$ Tris-borate buffer with a pGEM marker (Promega) (17).

The cells of all $C$. boidinii strains were long ovoid to cylindrical and formed pseudomycelia. Selected physiological characteristics are shown in Table 2 . All 19 strains studied exhibited the same results except for a few differences in the assimilation of sorbose, D-glucosamine, and L-arabinose. They showed the same characteristics as those described by Barnett et al. (1) and Meyer et al. (15).

Among the strains of $C$. boidinii studied, the major cellular

TABLE 2. Selected physiological characteristics of C. boidinit $^{a}$

\begin{tabular}{lccc}
\hline \multirow{2}{*}{$\begin{array}{c}\text { CCRC } \\
\text { strain }\end{array}$} & \multicolumn{3}{c}{ Assimilation $^{b}$} \\
\cline { 2 - 4 } & Sor & $\mathrm{GNH}_{2}$ & Ara \\
\hline $20464^{\mathrm{T}}$ & - & - & + \\
20472 & - & + & - \\
21432 & + & - & - \\
21483 & - & + & + \\
21758 & - & - & - \\
22516 & - & - & + \\
22517 & $\mathrm{D}$ & - & - \\
22518 & $\mathrm{D}$ & - & - \\
22519 & - & - & + \\
22520 & - & - & - \\
22521 & - & - & - \\
22522 & - & - & - \\
22523 & + & - & + \\
22524 & + & - & + \\
22525 & - & - & - \\
22526 & + & - & - \\
22527 & - & - & - \\
22528 & + & - & + \\
22529 & + & & - \\
\hline
\end{tabular}

${ }^{a}$ All strains fermented glucose and assimilated D-ribose, D-xylose, glycerol, ethanol, and nitrate. None of the strains assimilated D-galactose, L-rhamnose, trehalose, salicin, lactose, inulin, and starch.

${ }^{b}$ Sor, L-sorbose; $\mathrm{GNH}_{2}$, D-glucosamine; Ara, L-arabinose; +, positive; - , negative; $D$, delayed for longer than 7 days.
TABLE 3. Cellular fatty acid composition, ubiquinone systems, and DNA base composition of $C$. boidinii strains

\begin{tabular}{|c|c|c|c|c|c|c|c|c|c|c|}
\hline \multirow[t]{2}{*}{$\begin{array}{l}\text { CCRC } \\
\text { strain }\end{array}$} & \multicolumn{6}{|c|}{$\begin{array}{c}\text { Fatty acid } \\
\text { composition }(\%)^{a}\end{array}$} & \multicolumn{3}{|c|}{$\begin{array}{l}\text { Amt of the fol- } \\
\text { lowing ubiqui- } \\
\text { none isopre- } \\
\text { nologs }(\%)\end{array}$} & \multirow[t]{2}{*}{$\begin{array}{c}\mathrm{G}+\mathrm{C} \\
\text { content } \\
(\mathrm{mol} \%)\end{array}$} \\
\hline & $C_{14: 0}$ & $C_{16: 1}$ & $C_{16: 0}$ & $\mathrm{C}_{18: 2}$ & $\mathrm{C}_{18: 1}$ & $C_{18: 0}$ & Q-6 & Q-7 & Q-8 & \\
\hline $20464^{\mathrm{T}}$ & 1.2 & 16.5 & 19.5 & 36.1 & 24.3 & 2.5 & 2.3 & 95.0 & 2.7 & 31.0 \\
\hline 20472 & & 22.2 & 18.3 & 23.4 & 32.6 & 3.5 & 1.7 & 95.4 & 2.8 & 31.3 \\
\hline 21432 & & 16.2 & 20.1 & 35.2 & 25.4 & 3.1 & 3.0 & 95.8 & 1.2 & 32.8 \\
\hline 21483 & & 16.9 & 18.9 & 34.9 & 26.8 & 2.5 & 2.0 & 95.0 & 3.0 & 32.8 \\
\hline 21758 & 0.9 & 19.7 & 19.8 & 34.1 & 20.0 & 3.0 & 3.1 & 95.7 & 1.3 & 31.0 \\
\hline 22516 & 2.8 & 22.2 & 23.4 & 22.6 & 23.9 & 5.1 & 1.6 & 95.1 & 2.9 & 31.3 \\
\hline 22517 & 0.7 & 16.9 & 17.2 & 36.2 & 26.0 & 2.6 & 1.9 & 96.1 & 2.0 & 32.8 \\
\hline 22518 & 1.1 & 22.6 & 17.7 & 27.0 & 28.9 & 2.6 & 2.1 & 96.1 & 1.7 & 32.5 \\
\hline 22519 & 1.2 & 16.2 & 17.7 & 27.1 & 35.1 & 2.7 & 1.6 & $93 . i$ & 3.9 & 32.8 \\
\hline 22520 & 0.6 & 20.4 & 16.8 & 25.5 & 33.8 & 2.5 & 1.9 & 96.1 & 2.0 & 32.2 \\
\hline 22521 & 2.3 & 27.8 & 22.0 & 25.9 & 19.1 & 2.2 & 1.7 & 89.9 & 6.7 & 32.9 \\
\hline 22522 & 0.7 & 21.6 & 19.2 & 33.2 & 20.5 & 2.4 & 1.5 & 95.3 & 3.2 & 31.5 \\
\hline 22523 & 1.0 & 17.0 & 20.0 & 24.0 & 33.0 & 5.0 & 1.8 & 96.0 & 2.2 & 31.8 \\
\hline 22524 & 1.1 & 20.7 & 18.5 & 27.9 & 28.3 & 3.7 & 1.4 & 90.5 & 2.2 & 32.9 \\
\hline 22525 & 1.4 & 19.3 & 21.9 & 24.6 & 27.0 & 5.7 & 1.7 & 93.6 & 0.9 & 32.0 \\
\hline 22526 & 2.2 & 22.7 & 25.0 & 28.8 & 17.9 & 3.4 & 2.3 & 93.8 & 3.9 & 31.4 \\
\hline 22527 & 0.8 & 21.3 & 15.0 & 17.8 & 31.6 & 2.5 & 2.8 & 95.2 & 2.0 & 32.2 \\
\hline 22528 & 1.3 & 15.5 & 21.1 & 24.5 & 31.5 & 6.2 & 2.9 & 95.1 & 2.0 & 32.5 \\
\hline 22529 & 1.1 & 19.2 & 17.2 & 32.3 & 28.0 & 2.1 & 3.6 & 93.5 & 2.9 & 32.9 \\
\hline
\end{tabular}

fatty acid components were palmitoleic acid (15.5 to $22.2 \%)$, palmitic acid (15.0 to $25.0 \%$ ), linoleic acid (18.8 to $36.0 \%$ ), and oleic acid (18.0 to $36.0 \%$ ) (Table 3 ). Myristic acid (less than $2.8 \%)$ and stearic acid (2.1 to $5.7 \%)$ were detected as minor components. These characteristics were in agreement with the results reported by Viljoen and Kock (23). All strains tested had Q-7 as the major component (90 to $96 \%$ ) of the ubiquinone system, while Q-6 (1.4 to $3.6 \%)$ and Q-8 (0.9 to $6.7 \%)$ were detected as minor components (Table 3 ). The major ubiquinone of $C$. boidinii in this study was the same as that reported by Lee and Komagata (12).

The DNA base compositions of these strains ranged from 31.0 to $32.9 \mathrm{~mol} \% \mathrm{G}+\mathrm{C}$ (Table 3). Lee and Komagata (12) used the thermal denaturation method to determine $\mathrm{G}+\mathrm{C}$ contents and reported a similar range of 29.2 to $32.9 \mathrm{~mol} \%$ $\mathrm{G}+\mathrm{C}$ for eight strains of $C$. boidinii. Thus, some variation in the $\mathrm{G}+\mathrm{C}$ content in $C$. boidinii was observed.

The chromosomal DNA banding patterns of $C$. boidinii examined by pulsed-field gel electrophoresis are shown in Fig. 1. Polymorphisms in chromosomal DNA sizes and band numbers

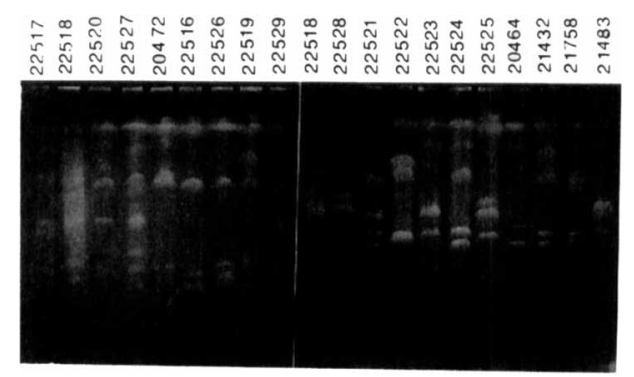

FIG. 1. Pulsed-field gel electrophoresis banding patterns of chromosomal DNAs isolated from $C$. boidinii. The conditions for CHEF were hexagonal electrode array, pulse time of 60 to $200 \mathrm{~s}$ for $24 \mathrm{~h}$ and then 200 to $600 \mathrm{~s}$ for 48 $\mathrm{h}$, and constant voltage at $100 \mathrm{~V}$. 


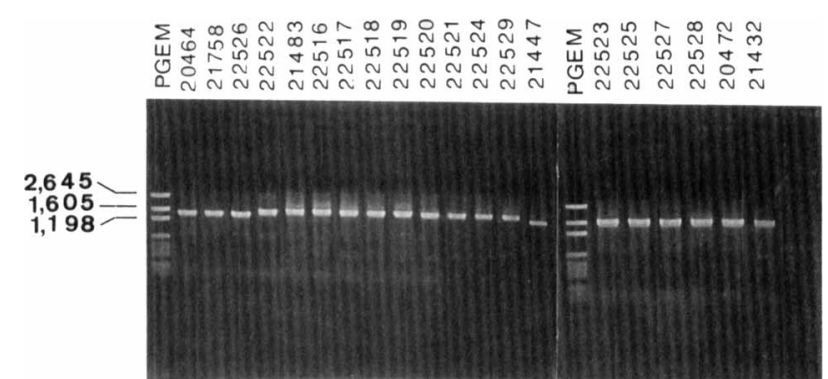

FIG. 2. Agarose gel electrophoresis of PCR amplification products from various strains of $C$. boidinii. These products were generated with primers 5S2 and ETS2, which were designed to amplify the $3^{\prime}$ ETS and the IGS regions of the rDNA repeat unit. PGEM, molecular weight standard. Saccharomyces cerevisiae CCRC 21447 was used as a reference.

were observed among the strains. Chromosome length polymorphisms in C. boidinii CCRC 21757, 21758, and 20464 have been reported by Lee et al. (10), and the chromosomal patterns of strains CCRC 21758 and 20464 were confirmed by our results.

The primers used in this study were found to successfully amplify a region of rDNA repeat unit that includes the ETS and the IGS which flank the $3^{\prime}$ end of the 18S-5.S-26S rRNA operon. The PCR amplification products from all strains were approximately $1,600 \mathrm{bp}$ long (Fig. 2). A certain degree of variability in the lengths of the amplification products from strains CCRC 20464, 21758, and 22526 was noted.

Selected restriction digests are shown in Fig. 3. Both HinfI and $D d e I$ yielded restriction patterns that separated $C$. boidinii
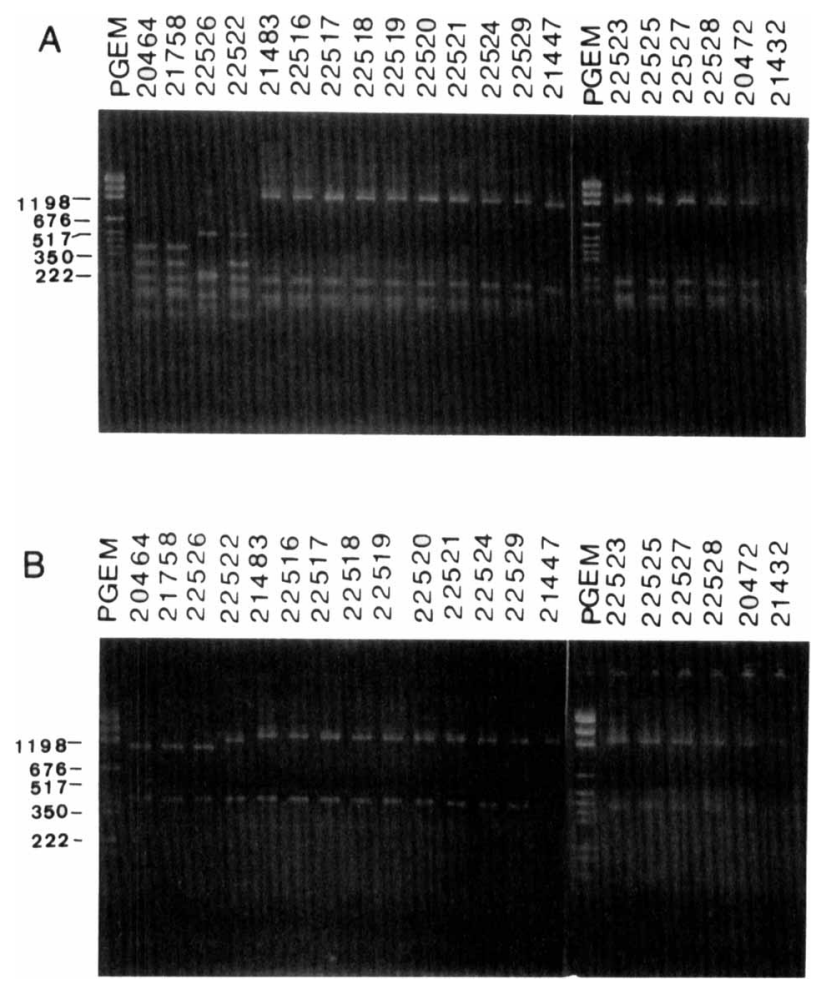

FIG. 3. Comparison of DdeI (A) and HinfI (B) restriction digests. PCR products of $C$. boidinii were digested with a series of restriction enzymes, and the resulting fragments were electrophoresed on 3\% NuSieve 3:1 agarose. PGEM molecular weight standard. S. cerevisiae CCRC 21447 was used as the reference.
CCRC 20464, 21758, 22522, and 22526 from the remaining strains. Fifteen strains of $C$. boidinii exhibited the same restriction patterns for the 10 enzymes used in this study. Although the coding region of the rDNA repeat unit exhibited a relatively high degree of evolutionary conservation, this degree of conservation could not be expected in the rDNA spacers. It has been found that the ETS and IGS spacers are highly variable between species and can be used to distinguish between closely related Saccharomyces species (17). The results that we obtained suggest that restriction polymorphisms in the rDNA spacer regions also exist in strains of $C$. boidinii. Two chemovarieties derived from different electrophoretic patterns of enzymes in $C$. boidinii (13) were clustered into their different patterns in the rDNA spacer region.

C. boidinii strains showed some variation in $\mathrm{G}+\mathrm{C}$ contents and exhibited polymorphisms in chromosomal patterns. These differences may be due to their different geographic origins (Table 1). We suggest that a relatively high degree of genetic heterogeneity exists in $C$. boidinii, and it is possible to divide the strains studied into two chemovarieties according to their different enzyme electrophoretic patterns and restriction profiles in rDNA spacer regions. Since the chromosomal pattern of $C$. boidinii is distinctive for each strain, CHEF electrophoresis could be a useful method for strain differentiation in this species. The combination of these molecular and chemotaxonomic characteristics can serve as a reliable tool for strain discrimination in culture authentication or industrial quality control. For further understanding of intraspecific relationships, the sequences of ETS and IGS regions and the levels of DNA relatedness should be determined.

We thank the Ministry of Economic Affairs, Republic of China, for financial support.

We thank K. Komagata, Tokyo University of Agriculture, for invaluable suggestions and T. Y. Liu, C. C. Liao, and G. F. Yuan, Food Industry Research and Development Institute, Taiwan, Republic of China, for their encouragement.

\section{REFERENCES}

1. Barnett, J. A., R. W. Payne, and D. Yarrow. 1990. Descriptions of the species, arranged alphabetically, p. 218. In Yeasts: characteristics and identification, 2nd ed. Cambridge University Press, Cambridge.

2. Billon-Grand, G. 1989. Influence on minor peaks of coenzyme $Q$ of the glucose concentration in the culture medium, the stage of the growth cycle, and the duration of coenzyme $\mathrm{Q}$ extraction: required conditions for determining the minor coenzyme Q. J. Gen. Appl. Microbiol. 35:261-268.

3. Carle, G. F., and M. V. Olson. 1985. An electrophoretic karyotype for yeast. Proc. Natl. Acad. Sci. USA 82:3756-3760.

4. Collins, M. D., T. Pirouz, and M. Goodfellow. 1977. Distribution of menaquinone in actinomycetes and corynebacteria. J. Gen. Microbiol. 100:221230.

5. Gorin, P. A. J., and J. F. T. Spencer. 1970. Proton magnetic resonance spectroscopy - an aid in identification and chemotaxonomy of yeasts. Adv. Appl. Microbiol. 13:25-89.

6. Ikemoto, S., K. Katoh, and K. Komagata. 1978. Cellular fatty acid composition in methanol-utilizing bacteria. J. Gen. Appl. Microbiol. 24:41-49.

7. Kaneko, Y., and I. Banno. 1991. Reexamination of Saccharomyces bayanus strains by DNA-DNA hybridization and electrophoretic karyotyping. IFO Res. Commun. 15:30-41.

8. Komagata, K. 1991. Systematics of methylotrophic yeasts, p. 25-37. In I. Goldberg and J. S. Rokem (ed.), Biology of methylotrophs. ButterworthHeinemann, Boston.

9. Kumamoto, T., M. Yamamoto, Y. Seriu, K. Kouno, R. Okamoto, T. Ishikura, and A. Takamatsu. 1986. Four new species of methanol-assimilating yeasts: Candida methanolophaga, Candida ovalis, Candida ooitensis and Pichia methylovora. Trans. Mycol. Soc. Jpn. 27:387-397.

10. Lee, C. F., F. L. Lee, and W. H. Hsu. 1994. Synonymy of Candida methylica with Candida boidinii and of Candida methanolophaga with Candida succiphila. Int. J. Syst. Bacteriol. 44:839-841.

11. Lee, J. D., and K. Komagata. 1980. Pichia cellobiosa, Candida cariosilignicola, and Candida succiphila, new species of methanol-assimilating yeasts. Int. J. Syst. Bacteriol. 30:514-519.

12. Lee, J. D., and K. Komagata. 1980. Taxonomic study of methanol-assimilating yeasts. J. Gen. Appl. Microbiol. 26:133-158. 
13. Lee, J. D., and K. Komagata. 1983. Further taxonomic study of methanolassimilating yeasts with special reference to electrophoretic comparison of enzymes. J. Gen. Appl. Microbiol. 29:395-416.

14. Magee, B. B., T. M. D'Souza, and P. T. Magee. 1987. Strain and species identification by restriction fragment length polymorphisms in the ribosomal DNA repeat of Candida species. J. Bacteriol. 169:1639-1643.

15. Meyer, S. A., D. G. Ahearn, and D. Yarrow. 1984. Genus 4. Candida Berkhout, p. 585-844. In N. J. W. Kreger-van Rij (ed.), The yeasts, a taxonomic study. Elsevier Science Publishers B.V., Amsterdam.

16. Molina, F. I., T. Inoue, and S. C. Jong. 1992. Ribosomal DNA restriction analysis reveals genetic heterogeneity in Saccharomyces cerevisiae Meyen ex Hansen. Int. J. Syst. Bacteriol. 42:499-502.

17. Molina, F. I., S. C. Jong, and J. L. Huffman. 1993. PCR amplification of the 3' external transcribed and intergenic spacers of the ribosomal DNA repeat unit in three species of Saccharomyces. FEMS Microbiol. Lett. 108:259-264.

18. Molina, F. I., D. Sen, and S. C. Jong. 1992. Determination of infraspecific relationships in Kluyveromyces marxianus by riboprinting. Mycotaxon 43:4960.

19. Smith, E. J., J. P. J. van der Westhuizem, J. L. Kock, and P. M. Lategan. 1987. A yeast identification method: the influence of culture age on the cellular long-chain fatty acid composition of three selected basidiomycetous yeasts. Syst. Appl. Microbiol. 10:38-41.

20. Tamaoka, J., and K. Komagata. 1984. Determination of DNA base composition by reversed-phase high performance liquid chromatography. FEMS Microbiol. Lett. 25:125-128.

21. van der Walt, J. P., and D. Yarrow. 1984. Methods for isolation, maintenance, classification and identification of yeasts, p. 45-104. In N. J. W. Kreger van Rij (ed.), The yeasts, a taxonomic study. Elsevier Science Publishers B.V., Amsterdam.

22. Vilgalys, R., and M. Hester. 1990. Rapid genetic identification and mapping of enzymatically amplified ribosomal DNA from several Cryptococcus species. J. Bacteriol. 172:4238-4246.

23. Viljoen, B. C., and J. L. F. Kock. 1989. A taxonomic study of the yeast genus Candida Berkhout. System. Appl. Microbiol. 12:91-102.

24. Vollrath, D., and R. W. Davis. 1987. Resolution of DNA molecules greater than 5 megabases by contour-clamped homogeneous electric field. Nucleic Acids Res. 15:7865-7876.

25. Wegner, G. H. 1990. Emerging applications of the methylotrophic yeasts. FEMS Microbiol. Rev. 87:279-284. 